\title{
Survey of Leptospira spp in pampas deer (Ozotoceros bezoarticus) in the Pantanal wetlands of the state of Mato Grosso do Sul, Brazil by serology and polymerase chain reaction
}

\author{
Anahí Souto Vieira ${ }^{1 /+}$, Grácia Maria Soares Rosinha ${ }^{2}$, Carina Elisei de Oliveira ${ }^{2}$, \\ Silvio Arruda Vasconcellos ${ }^{3}$, Paulo Andre Lima-Borges ${ }^{4}$, Walfrido Moraes Tomás ${ }^{5}$, \\ Guilherme Miranda Mourão ${ }^{5}$, Ana Cristina Reis Lacerda ${ }^{6}$, Cleber Oliveira Soares ${ }^{2}$, \\ Flábio Ribeiro de Araújo ${ }^{2}$, Ubiratan Piovezan ${ }^{5}$, Carlos Andre Zucco ${ }^{7}$, Aiesca Oliveira Pellegrin ${ }^{5}$

\begin{abstract}
1Programa de Pós-Graduação em Ciência Animal 'Programa de Pós-Graduação em Ecologia e Conservação, Universidade Federal do Mato Grosso do Sul, 79070-900 Campo Grande, MS, Brasil ²Embrapa Gado de Corte, Campo Grande, MS, Brasil ${ }^{3}$ Departamento de Medicina Veterinária Preventiva e Saúde Animal, Faculdade de Medicina Veterinária e Zootecnia, Universidade de São Paulo, São Paulo, SP, Brasil ${ }^{4}$ Independent Consultant on Veterinary, Brasília, DF, Brasil

${ }^{5}$ Embrapa Pantanal, Corumbá, MS, Brasil ${ }^{6}$ Programa de Pós-graduação em Biologia Animal, Universidade de Brasília, Brasília, DF, Brasil
\end{abstract}

This work reports a survey of Leptospira spp in pampas deer (Ozotoceros bezoarticus) in the Pantanal wetlands of the state of Mato Grosso do Sul, Brazil by serology and polymerase chain reaction (PCR). Seventy pampas deer were captured in the dry season and surveyed using PCR, microscopic agglutination test (MAT) $(n=51)$ and by both techniques $(n=47)$. PCR detected infections in two pampas deer and MAT detected infections in three. Through sequencing and phylogenetic analyses, the PCR-amplified fragment detected in deer was identified as Leptospira interrogans. Serovars Pomona and Butembo were detected using MAT and the highest titre was 200 for serovar Pomona. Epidemiological aspects of the findings are discussed.

Key words: pampas deer - Leptospira spp - MAT - PCR - Pantanal

Leptospirosis is a worldwide disease (Scarcelli et al. 2003) responsible for important reproductive losses in cattle and severe zoonosis in man and domestic animals. Reports of leptospirosis in wildlife that share habitats with cattle are increasing (Mathias et al. 1999, Bengis et al. 2002, Girio et al. 2003, Scarcelli et al. 2003, Deem et al. 2004). Because of the expansion of cattle ranching into areas traditionally occupied by wildlife, such as the Pantanal wetlands in the state of Mato Grosso do Sul (MS), Brazil, interest in pathogens that affect native and livestock populations simultaneously has become more important.

The cervids belong to the order Artiodactyla, family Cervidae (Emmons \& Feer 1990, Eisemberg \& Redford 1999). In the Pantanal wetlands there are four species of cervids, Blastocerus dichotomus (marsh deer), Ozotoceros bezoarticus (pampas deer), Mazama americana (red brocket deer) and Mazama gouazoubira (brown brocket deer), which have distinct habitats (Vaughan 1986, Rodrigues et al. 2002, Tomás et al. 2004, Tiepolo \& Tomás 2006).

Populations of pampas deer are distributed all over the Pantanal, with higher densities in the fields and ebbs (Mourão et al. 2000, Tomás et al. 2001, 2004). There are more pampas deer in the Pantanal than in the Cerrado biome; these two populations are sympatric (Rodrigues

+ Corresponding author: anahi_sv@yahoo.com.br

Received 13 September 2010

Accepted 13 June 2011 et al. 2002). The region of Nhecolândia has the highest population density of pampas deer in the Pantanal, estimated to be approximately 60 thousand individuals (Mourão et al. 2000).

In the Pantanal, ecological conditions are highly suitable for Leptospira spp, mainly because of the high temperatures and pluviometric index (1,200 $\mathrm{mm} /$ year) (Garcia \& Castro 1986, Lins et al. 1986).

Leptospirosis is diagnosed by the detection of specific antibodies using microscopic agglutination test (MAT) and the isolation of the Leptospira pathogen in culture media. However, both techniques are laborious and time consuming. MAT requires the use of live antigens and the culture technique demands freshly collected samples (Faine et al. 1999, Cerqueira \& Picardeu 2009).

Polymerase chain reaction (PCR) has been used for the diagnosis of leptospirosis in humans and domestic animals, demonstrating high accuracy and sensitivity when compared with MAT (Van Eys et al. 1989, Gerristsen et al. 1991, Radstone \& Woodward 1996).

The objectives of this work were to estimate the prevalence of pampas deer infected with Leptospira spp in the Pantanal wetlands of MS, to identify the infective serovars and to evaluate a PCR method to detect these pathogens, assessing the analytic sensitivity.

The study was conducted in four contiguous ranches located in the central area of the Pantanal, known as Nhecolândia (18 59'115''S 56³7'63' N), over an area of approximately 40,000 ha. The captures were performed from May-November 2006. Nhecolândia has the highest density population of pampas deer in the Pantanal; its population is estimated to be approximately 60,000 
animals (Mourão et al. 2000). The surveyed area included private beef cattle ranches with land areas between 4,000-20,000 ha. In these ranches, cow-calf operations were based on extensive breeding on natural pastures.

Pampas deer were captured using anaesthetic darts shot with $\mathrm{CO}_{2}$ guns with adjustable pressure (Distinject, model 35) or a blowpipe of $2 \mathrm{~m}$ length $\mathrm{x} 11 \mathrm{~mm}$ diameter (Zootech). Chemical anaesthesia with tiletamine/ zolazepam or zolazepam/xylazine was administered to 42 animals (Piovezan et al. 2006) and a combination of zolazepam, tiletamine, xylazine and atropine was administered to 60 animals (Lima-Borges et al. 2006).

The environmental licenses for captures were provided by Brazilian Institute of Environment and Renewable Natural Resources (032/2005-0214.0022008/05-00 and 005/2007-02014.000382/2007-22). Blood samples were taken from the jugular vein into tubes with or without anticoagulant ethylenediamine tetraacetic acid. After centrifugation, serum and erythrocyte layers were used for MAT and PCR, respectively.

Antibodies against Leptospira spp were detected by MAT according to Cole et al. (1973) using a routine panel of 19 live antigens of Leptospira spp and nine field isolates from domestic and wild animals. The panel represented the following serovars and strains of Leptospira spp: Australis (Ballico), Bratislava (Jez Bratislava), Autumnalis (Akiyami A), Castellonis (Castellon), Batavie (van Tienen), Butembo (Butembo), Canicola (Hond Utrecht IV), Whitcombi (Whitcombi), Cynopteri (3522-C), Grippotyphosa (Moskva V), Hebdomadis (Hebdomadis), Copenhageni (M-20), Icterohaemorrgagiae (RGA), Javanica (Veldrat Batavia 46), Panamá (CZ 214), Pomona (Pomona), Pyrogenes (Salinem), Hardjo (Hardjoprajitno), Wolffi (3705), Hardjo (Hardjobovis), Shermani (1342 K), Tarassovi (Perpelitsin), Sentot (Sentot) and Patoc (Patoc 1). The panel of field isolates used as MAT antigens were represented by serovars Brasiliensis (isolated in Didelphis marsupialis), Pomona (Sus scrofa), Guaricura (Bubalus bubalis), Copenhageni (Rattus norvegicus), Canicola (Canis familiaris), Canicola (Bos taurus), Grippothyphosa (Hidrochaeris hidrochaeris) and a non-characterised isolate of Cerdocyum thous captured in the study area. The reference strains were provided by the following centres: Department of Microbiology, Institute of Biomedical Sciences, University of São Paulo (USP) (Dr Paulo Hideki Yasuda); Institute of Veterinary Medicine Robert Von Ostertag (Berlin) (Dr Arno Schönberg); Zoonoses Control Centre of São Paulo (Dra Maria das Graças Matsuo); Oswaldo Cruz Foundation/Rio de Janeiro (Katya Avelar). Field isolates were provided by: Biological Institute São Paulo; Centre for Disease Control and Prevention [United States of America (USA)]; Faculty of Veterinary Medicine and Animal Science (USP); Zoo Foundation São Paulo; State University of Londrina; Brazilian Agricultural Research Corporation Pantanal.

Living cultures of leptospires grown for four-14 days in $\mathrm{EMJH}$ medium (Difco) at $28-30^{\circ} \mathrm{C}$ were used as the antigen suspension. The serum to be tested was serially diluted starting from a 1/50 dilution using two-fold dilutions $(1 / 50,1 / 100,1 / 200,1 / 400$ and 1/800) and the same volume of antigen suspension was added to each well and mixed by agitation. The suspension in each well was examined microscopically for agglutination. The end point was the final dilution of serum at which $50 \%$ of the leptospires were agglutinated and the cut-off considered to be a positive reaction was a titre greater or equal to 100 (Faine et al. 1999).

Purification of genomic DNA was performed according to Araujo et al. (2009) and a positive control of Leptospira interrogans, serovar hardjoprajitno was obtained from culture in semi-solid media (Fletcher, Difco). The primers used in this study were described by Mérien et al. (1992). Reactions were prepared in a total volume of $20 \mu \mathrm{L}$ and the parameters used in the amplification were standardised in this work: $95^{\circ} \mathrm{C}$ for $4 \mathrm{~min}$, followed by 30 cycles at $95^{\circ} \mathrm{C}$ for $30 \mathrm{sec}$, annealing at $58^{\circ} \mathrm{C}$ for $30 \mathrm{sec}$ and extension at $72^{\circ} \mathrm{C}$ for $60 \mathrm{sec}$ and a final extension at $72^{\circ} \mathrm{C}$ for $10 \mathrm{~min}$. PCR products were submitted to electrophoresis on a $1 \%$ agarose gel stained with SYBR Gold (Invitrogen) and visualised under ultraviolet light.

For the assessment of analytical sensitivity, the genomic DNA of $L$. interrogans serovar was diluted serially (10-fold) to $1: 10^{-7}$ starting from $280 \mathrm{ng} / \mu \mathrm{L}$ and each dilution was analysed by PCR using same protocol described above. The specificity of the PCR technique was evaluated by testing all the antigens used in MAT. PCR products were cloned into the pGEM-T Easy plasmid (Promega) using Escherichia coli TOP10 F' chemically competent host cells. Purification of recombinant plasmids was performed with the Wizard Miniprep kit (Promega). The resulting clones were sequenced in both directions using the BigDye Terminator Cycle Sequencing Ready Reaction kit (Applied Biosystems). Sequences were submitted to a homology search by the BLASTn algorithm (blast.ncbi.nlm.nih.gov/Blast.cgi).

The phylogenetic analyses were conducted with DNA sequences of Leptospira using the MEGA software program, version 4.0 (Tamura et al. 2007) and a phylogenetic tree was generated using the neighbour-joining method (Saitou \& Nei 1987) and a bootstrap resampling technique of 1,000 replications to statistically support the reliabilities of the nodes on the trees (Felsenstein 1985). Leptospira biflexa Patoc, Leptonema ilinni Illini and Tuneria parva Parva were used as outgroups (Morey et al. 2006).

Fifty-one serum samples of pampas deer were tested by MAT and three $(5.9 \%)$ were positive for serovars Pomona (2/3) and Butembo (1/3) with titres of 100 and 200 , respectively. Two out of 70 blood samples tested for Leptospira spp using PCR were positive [confidence interval (CI) $95 \%, 0.0020-0.1042]$. Because this technique employed blood samples, two positive samples could indicate an acute infection, as leptospiremia usually persists seven-15 days after infection (Faine 1982). For example, the Pomona serovar may be isolated from white-tailed deer blood on the 4th day after experimental inoculation with this serovar (Ferris et al. 1960) and a low level of PCR-detection of infected animals is plausible except in outbreaks or when leptospirosis has recently been introduced into an area or a herd, with a large number of susceptible animals becoming infected. 
A 5.9\% frequency of Leptospira antibodies (CI 95\%, 0.0141-0.1654) was found using MAT testing and the serovar Pomona was the most frequently detected. These results differ from those reported by Mathias et al. (1999), who found a seroprevalence of $24 \%$ with the Hardjo serovar being the most frequent in the same region. According to several authors, Hardjo is the most frequent serovar found in deer and cattle both in the Pantanal and in MS (Madruga et al. 1980, Pellegrin et al. 1999, Favero et al. 2001). Pellegrin et al. (1999) screened 756 cattle sera from the same cattle ranches where deer live against a reference panel of 17 leptospiral serovars using MAT and reported a frequency of $38 \%$ positive sera. The most prevalent serovars were Hardjo, Wolffi and Sejroe and only three sera reacted to serovar Pomona. Tomich et al. (2007) screened 282 samples of cattle serum and detected $143(50.71 \%)$ positive samples with MAT and confirmed that the most prevalent serovars were Hardjo (genotypes Hardjoprajitno and Hardjobovis) and Wolffi. In the same work, the authors found that $57.09 \%$ of the sera were positive for IgG in a recombinant LipL32 enzyme-linked immunosorbent assay. Differences in the prevalence of Leptospira spp infections in different regions may reflect true variations or may result from differences in the study designs, including the method of sampling, panel of serovars or MAT cut-off values. One study indicated that the earliest agglutination to serovar Pomona in white-tailed deer appeared six days after inoculation and titres of 10 could be detected from the seventh-12th day (Ferris et al. 1960).

The results obtained in this study agree with those obtained by Girio et al. (2003), who recorded four infected pampas deer (9.7\%) by performing MAT in samples from 41 animals and did not detect the presence of Leptospira spp in the kidney and liver of animals that died during capture. However, there was some disagreement between the results presented here and those obtained by Girio et al. (2003), who found a high frequency of reactions to serovar Wolffi. In the present study, there was an increased frequency of reactions to serovar Pomona maintained by pigs under natural conditions.

In this survey, data for sex and age are presented, but no analysis was performed because only five deer were positive by MAT or PCR: two females and three

\section{TABLE}

Frequency of pampas deer (Ozotoceros bezoarticus) positive for Leptospira spp in the Pantanal of the state of Mato Grosso do Sul, Brazil, by microscopic agglutination test (MAT) and polymerase chain reaction (PCR)

\begin{tabular}{lcccccc}
\hline Test & $\begin{array}{c}\text { Animals } \\
(\mathrm{n})\end{array}$ & $\begin{array}{c}\text { Positives } \\
(\%)\end{array}$ & \multicolumn{2}{c}{$\begin{array}{c}\text { Sex } \\
(\mathrm{n})\end{array}$} & \multicolumn{2}{c}{$\begin{array}{c}\text { Age } \\
(\mathrm{n})\end{array}$} \\
\hline & & & Male & Female & Adult & Fawn \\
\cline { 3 - 7 } & & & 31 & 39 & 52 & 18 \\
PCR & 70 & $2(2.04)$ & 37 & 37 & 14 \\
MAT & 51 & $3(5.9)$ & 24 & 27 &
\end{tabular}

males. Ferris and Verts (1964) performed a survey of 319 hunted white-tailed deer during the 1959 and 1960 deer hunting seasons in Illinois (USA) and reported 32 reactions by MAT and evidence that these findings seem to be unrelated to the sex and age of the animals.

PCR was able to amplify up to $280 \mathrm{fg} / \mu \mathrm{L}$ of DNA from the positive control. A visible product could be detected on a $1 \%$ agarose gel stained with SYBR Gold up to a $1: 10^{-6}$ dilution and the Lep1 and Lep2 primers amplified all the serovars utilised in this study for MAT. The two PCR products obtained from the positive samples were cloned and sequenced. In a BLASTn search, the DNA sequence from sample 2 showed $100 \%$ identity and an e-value of $10^{-172}$ with the closest match, L. interrogans serovar Australis, accession FJ154557.1. Sample 31 showed $99 \%$ identity and an e-value of $10^{-104}$ with best the hit, L. interrogans serovar Copenhageni, accession FJ154558.1. The phylogenetic analysis resulted in a tree with L. biflexa, L. ilinni and T. parva as outgroups (Morey et al. 2006) and another large group of pathogenic leptospires. The samples from pampas deer were grouped in the L. interrogans branch.

The results from this study show that leptospirosis occurs in cervids in the Pantanal wetlands of MS. Because $O$. bezoarticus cohabits with cattle, this may represent a risk for livestock and for other wildlife species. By sequencing the PCR products detected in pampas deer from the Pantanal and searching for homology using the BLASTn algorithm, two serovars were detected, Australis and Copenhageni. Australis has been found in equines, however, without clinical signs (Pinho et al. 2007, Maciel et al. 2008). The reservoirs of serovar Copenhageni are usually rodents, but this serovar has been isolated in several species, causing clinical alterations in accidental hosts (Rodrigues 2008). Girio et al. (2003) already detected antibodies to the Copenhageni serovar in cervids in the Pantanal by MAT, consistent with the current findings; however, the findings of this present study need further confirmation, as the primers used amplify a conserved region of the 16S rRNA gene of Leptospira spp.

In a survey of 44 cervids in captivity, Silva et al. (2010) detected 19 (43.1\%) infections with the following serovars: seven $(36.8 \%)$ ) for Autumnalis, six (31.5\%) for Andamana, six (31.5\%) for Icterohaemorrhagiae, six $(31.5 \%)$ for Patoc and five $(26.3 \%)$ for Canicola. In the same work, other species of domestic and wild animals were surveyed and the same serovars were detected. Jorge et al. (2011) carried out work in the Social Service of Commerce Pantanal Reserve with wild carnivores, domestic dogs and wild horses and found the same serovars. In another work, Mathias et al. (1999) did not show the same positive findings found in these two works.

The low frequency of infection obtained in this study can be explained because deer were captured mostly during the dry season, from May-November, when the suitable conditions of flooded habitats do not exist to allow the survival of large numbers of leptospires. Large numbers of leptospires can survive for long periods in water or soil. Infected animals contaminate pastures, yards, drains, soil and surface waters with leptospires from their urine and leptospirosis has a higher preva- 
lence in tropical regions, especially following periods of heavy rainfall (Faine et al. 1999, Haake et al. 2002). Additionally, MAT is a technique of low sensitivity, mainly to the Hardjo serovar in cattle because some renal carriers present no detectable antibody titres or titres less than the current reference cut-off of 1/100 (Ellis et al. 1981). Cut-off values of $1 / 30$ for serovar Hardjo and $1 / 100$ for the other serovars can be used for the screening of leptospirosis in cattle herds (Alonso-Andicoberry et al. 2001). MAT is not standardised for the diagnosis of leptospirosis in wild animals or at lower cut-offs, which would improve its sensitivity in testing cervids (Espi et al. 2000). Sequence-based molecular phylogeny of the fragment obtained by PCR in deer suggested that the infective serovar is a $L$. interrogans genomospecies, but this could not confirm because this isolate was not recovered from any surveyed deer. Results from MAT led to the hypothesis that feral pig (Sus scrofa feral), which is one of the largest biomasses in the Pantanal (Mourão et al. 2002), could be involved in the transmission of serovar Pomona to pampas deer because surveys conducted in cattle from the Pantanal showed that serovar Pomona is not frequent in cattle (Pellegrin et al. 1999), despite the fact that Girio et al. (2003) found a high frequency of this serovar in buffalo and sheep in the same area. Serovar Pomona has also been reported in other species of deer, such as Odocoileus virginianus (Ingebrigtsen et al. 1986, Goyal et al. 1992), Cervus elaphus hispanicus (Iberian red deer), and Dama dama (fallow deer) (Espi et al. 2010).

Serovar Butembo has been found in cattle and pampas deer in Southern Brazil (Saldanha et al. 2007, Tonin et al. 2011). Serum samples of repeat breeder cows in São Lourenço do Oeste, state of Santa Catarina, were surveyed for leptospiral anti-agglutinins and $100 \%$ were positive for serovar Butembo, with titres between 100800. After treatment with streptomycin sulphate, $92 \%$ of the cows recovered from reproductive disorders. In a case report, Tonin et al. (2011) described severe symptoms of clinical leptospirosis in a pampas deer, such as jaundice, weakness and weight loss, and the results of MAT against a panel of eight reference serovars demonstrated seropositivity for serovars Butembo $(1 / 200)$, Bratislava (400), Wolffi (200) and Hardjo (400). Cattle and farmed deer in New Zealand are recognised as a maintenance host for serovar Hardjo and pigs for serovar Pomona. However, the interpretation of leptospiral titres can vary according to the serovar: Hardjobovis and Bratislava generally present lower titres compared with Pomona (Ayanegui-Alcerreca 2006), but Pomona can cross react with Bratislava; therefore, using lower cut-offs in the MAT can lead to an overestimation of the number of infections by serovar Pomona. Wild boar and feral pigs frequently have an adverse impact on agriculture and the environment. Feral pigs are an exotic, invasive pest species in many areas of the world and can introduce diseases to livestock populations (Bengis et al. 2002). In some parts of Europe, wild boar is an increasingly abundant native species (Artois et al. 2002) and can be infected by Leptospira spp (Espi et al. 2010).
These results suggest that, for the studied area, the role of cattle in the spread of serovar Hardjo to pampas deer is questionable and that pampas deer may be involved in the disease cycle of serovar Pomona more than for Hardjo. This observation is consistent with the findings of previous studies (Fournier et al. 1986). The source of serovar Pomona for deer and cattle could be other wildlife, in particular feral pigs and wild boar (Espi et al. 2010). These results indicate that pampas deer are exposed to Leptospira organisms, but further studies on leptospirosis in pampas deer, feral pigs and cattle are required to explain the relationship between these species in the epidemiology of leptospirosis in the Pantanal.

\section{REFERENCES}

Alonso-Andicoberry C, Garcia-Pena FJ, Pereira-Bueno J, Costas E, Ortega-Mora LM 2001. Herd-level risk factors associated with Leptospira spp. Seroprevalence in dairy and beef cattle in Spain. Prev Vet Med 52: 109-117.

Araujo FR, Ramos CAN, Luiz HL, Perez IAHFS, Oliveira RHM, Souza ILF, Russi LS 2009. Avaliação de um protocolo de extração de DNA genômico a partir de sangue total, Comunicado Técnico 120, Embrapa GNPGC, Campo Grande, 5 pp.

Artois KR, Depner V, Guberti J, Hars S, Rossi D 2002. Rutili, classical swine fever (hog cholera) in wild boar in Europe. Rev Sci Tech 21: 287-303.

Ayanegui-Alcerreca MA 2006. Epidemiology and control of leptospirosis in farmed deer in New Zealand, PhD Thesis, Massey University, Palmerston North, 353 pp.

Bengis RG, Kock RA, Fisher J 2002. Infectious animal diseases: the wildlife/livestock interface. Rev Sci Tech 21: 53-65.

Cerqueira GM, Picardeau M 2009. A century of Leptospira strain typing. Infect Genet Evol 9: 760-768.

Cole JR, Sulzer CR, Pursell AA 1973. Improved microtechnique for the leptospiral microscopic agglutination test. Appl Microbiol 25: 976-980.

Deem SL, Noss AJ, Villarroel R 2004. Disease survey of free-ranging Grey Brocket Deer (Mazama gouazoubira) in the gram Chaco, Bolivia. J Wildl Dis 40: 92-98.

Eisemberg JF, Redford KH 1999. Mammals of the Neotropics: the Central Neotropics 3, University Chicago Press, Chicago, 609 pp.

Ellis WA, O'Brien JJ, Cassells J 1981. Role of cattle in the maintenance of Leptospira interrogans serotype hardjo infection in North Ireland. Vet Rec 108: 555-557.

Emmons LH, Feer F 1990. Neotropical rainforest mammals: a field guide, University of Chicago Press, Chicago, 281 pp.

Espi A, Pietro JM, Alzaga V 2010. Leptospiral antibodies in Iberian red deer (Cervus elaphus hispanicus), fallow deer (Dama dama) and European wild boar (Sus scrofa) in Asturias, Northern Spain. Vet $J$ 183: 226-227.

Faine S 1982. Guidelines for the control of leptospirosis, World Health Organization, Geneva, $171 \mathrm{pp}$.

Faine S, Adler B, Bolin C, Perolat P 1999. Leptospira and leptospirosis, 2nd ed., MediSci, Melbourne, $272 \mathrm{pp}$.

Favero M, Pinheiro SR, Vasconcellos SA, Morais ZM, Ferreira F, Ferreira Neto JS 2001. Leptospirose bovina: variantes sorológicas predominantes em colheitas efetuadas no período de 1984 a 1997 em rebanhos de 21 estados do Brasil. Arq Inst Biol 68: 29-35. 
Felsenstein J 1985. Confidence limits on phylogenies: an approach using the bootstrap. Evolution 39: 783-791.

Ferris DH, Hanson LE, Hoerlein AB, Beamer PD 1960. Experimental infection of white-tailed deer with Leptospira pomona. Cornell Vet 50: 236-250.

Ferris DH, Verts BJ 1964. Leptospiral reactor rates among whitetailed deer and livestock in Carroll County, Illinois. $J$ Wild Manag 28: 35-41.

Fournier JS, Gordon JC, Dorn CR 1986. Comparison of antibodies to leptospira in white-tailed deer (Odocoileus virginianus) and cattle in Ohio. $J$ Wildl Dis 22: 335-339.

Garcia EA, Castro LHR 1986. Análise da frequência de chuva no Pantanal Mato-Grossense. Pesq Agropec Bras 2: 909-925.

Gerristsen MJ, Olyhoek T, Smits MA, Bokhout BA 1991. Sample preparation method for polymerase chain reaction-based semiquantitative detection of Leptospira interrogans sorovar Hardjo subtype Hardjobovis em bovine urine. J Clin Microbiol 29: 2805-2808.

Girio RJS, Pereira FLG, Filho MM, Mathias LA, Herreira RCP, Alessi AC, Girio TMS 2003. Pesquisa de anticorpos contra Leptospira spp em animais silvestres em estado feral da região da Nhecolândia, Mato Grosso do Sul, Brasil. Utilização da técnica de imunohistoquímica para a detecção do agente. Cienc Rural 34: 165-169.

Goyal SM, Mech LM, Nelson ME 1992. Prevalence of antibody titers to Leptospira spp in Minnesota white-tailed deer. $J$ Wildl Dis 28: 445-448.

Haake DA, Dundoo M, Cader R, Kubak BM, Hartskeerl RA, Sejvar JJ, Ashford DA 2002. Leptospirosis, water sports and chemoprophylaxis. Clin Infect Dis 34: 40-43.

Ingebrigtsen DK, Ludwing JR, Mcclurkin AW 1986. Occurrence of antibodies to the etiologic agents of infectious bovine rhinotracheits, parainfluenza 3, leptospirosis and brucellosis in whitetailed deer in Minnesota. J Wildl Dis 22: 83-86.

Jorge RSP, Ferreira F, Ferreira Neto JS, Vasconcellos SA, Lima ES, de Morais ZM, de Souza GO 2011. Exposure of free-ranging wild carnivores, horses and domestic dogs to Leptospira spp in the northern Pantanal, Brazil. Mem Inst Oswaldo Cruz 106: 441-444.

Lima-Borges PA, Tomas WM, Lacerda ACR 2006. Contenção de Ozotoceros bezoarticus no Pantanal com associação zolazepan + tiletamina + xilazina + atropina e reversão com ioimbina. In Anais do VII Congresso Internacional sobre o Manejo da Fauna Silvestre, Ilhéus, 389 pp.

Lins ZC, Lopez ML, Maroja OM 1986. Bacteriologia: epidemiologia das leptospirose com particular referência à Amazônia brasileira. In Instituto Evandro Chagas, 50 anos de contribuição a ciências biológicas e a medicina tropical, Ministério da Saúde, Belém, p. 733-764.

Maciel RM, Lopez STA, Martins DB, Franciscato C, Merini LP, Costa MM, Badke MRT, Gonçalves AP, Veiga APM, Mühlen RV 2008. Incidência de aglutininas anti-leptospira em soro de eqüinos utilizados na tração de carroças no município de Santa Maria - RS. In Anais do XXXV Congresso Brasileiro de Medicina Veterinária, Gramado, p. 1-5.

Madruga CR, Aycardi E, Putt N 1980. Freqüência de aglutininas antileptospira em bovinos de corte na região sul de Cerrado do estado de Mato Grosso. Arq Esc Vet UFMG 32: 245-249.

Mathias LA, Girio RJS, Duarte JMB 1999. Serosurvey for antibodies against Brucella abortus and Leptospira interrogans in pampas deer from Brazil. J Wildl Dis 35: 112-114.

Mérien FP, Amouriaux P, Perlota P, Baranton G, Saint Girons I 1992. Polymerase chain reaction for detection of Leptospira spp in clinical samples. J Clin Microbiol 30: 2219-224.
Morey RE, Galloway RL, Bragg SL, Steigerwalt AG, Mayer LW, Levett PN 2006. Species-specif identification of Leptospiraceae by $16 S$ rRNA gene sequencing. J Clin Microbiol 44: 3510-3516.

Mourão G, Coutinho M, Mauro R, Campos Z, Tomas W, Magnusson W 2000. Aerial surveys of caiman, marsh deer and pampas deer in the Pantanal Wetland of Brazil. Biol Conservation 92: 175-183.

Mourão GM, Coutinho ME, Mauro RA 2002. Levantamentos aéreos de espécies introduzidas no Pantanal: porcos ferais (porco monteiro), gado bovino e búfalos, Comunicado técnico 28, Embrapa CPAP, Corumbá, 22 pp.

Pellegrin AO, Guimarães PHS, Sereno JRB, Figueiredo JP, Lage AP, Moreira EC, Leite RC 1999. Prevalência da leptospirose em bovinos do Pantanal Mato-Grossense, Comunicado Técnico 22, Embrapa CPAP, Corumbá, 9 pp.

Pinho APB, Moraes CCG, Santos RB, Dias HLT, Meneses AMC, Oliveira AL, Silva JS, Sena NM, Vasconcellos SA 2007. Sorovares de Leptospira interrogans e respectivas ocorrências em eqüídeos de tração da ilha de Maiandeua (Algodoal), Pará. Arq Int Biol 69: 113-198.

Piovezan U, Zucco AC, Lopes FRE 2006. Uso de dardos anestésicos para a captura de veados campeiros (Ozotoceros bezoarticus) no Pantanal, Boletim de Pesquisa e Desenvolvimento 71, Embrapa CPAP, Corumbá, 22 pp.

Radstone JS, Woodward MJ 1996. The development of a ligase mediated PCR with potential for the differentiation of serovars within Leptospira interrogans. Vet Microbiol 51: 351-362.

Rodrigues AMA 2008. Leptopsirose canina; diagnostico etiológico, sorológico e molecular e avaliação da proteção cruzada entre os sorovares icterohaemorrhagiae e copenhageni, MSc Thesis, Universidade de São Paulo, São Paulo, 116 pp.

Rodrigues FHG, Medri IM, Tomas WM, Mourão GM 2002. Revisão do conhecimento sobre ocorrência e distribuição de mamíferos do Pantanal, Comunicado técnico 38, Embrapa CPAP, Corumbá, $41 \mathrm{pp}$.

Saitou N, Nei M 1987. The neighbour-joining method: a new method for reconstructing phylogenetic trees. Mol Bio Evol 4: 406-425.

Saldanha GBS, Cavazini NC, Silva AS, Fernandes MB, Badken MRT, Pivetta CG 2007. Sorologia positiva para Leptospira butembo em bovinos apresentando problemas reprodutivos. Cienc Rural 37: 1182-1184.

Scarcelli E, Piatti RM, Fedullo JDL, Simon F, Cardoso MV, Castro V, Myashiro S, Genovez ME 2003. Leptospira spp detection by polymerase chain reaction (PCR) in clinical sample of captitive Black-capped Capution Monkey (Cebus apella). Braz J Microbiol 34: 143-146.

Silva FJ, Mathias LA, Magajevski FS, Werther K, Assis NA, Girio RJS 2010. Anticorpos contra Leptospira spp em animais domésticos e silvestres presente no campus universitário da FCAV, UNESP, Jabuticabal/SP. ARS Veterinaria 26: 17-25.

Tamura K, Dudley J, Nei M, Kumar S 2007. MEGA 4: Molecular Evolutionary Genetics Analysis (MEGA) software version 4.0. Mol Biol Evol 24: 1596-1599.

Tiepolo LM, Tomás WM 2006. Ordem Artiodactyla. In NR Reis, AL Peracchi, WA Pedro, IP Lima, Mamíferos do Brasil, Universidade Estadual de Londrina, Londrina, p. 283-303.

Tomás WM, Mcshea W, Miranda GHB, De Moreira JR, Mourão GE, Lima Borges PA 2001. A survey of pampas deer, Ozotoceros benzoarticus leucogaster (Artiodactyla, Cervidae) population in the Pantanal Wetetland, Brazil using the distance sampling technique. Anim Biod Conserv 24: 101-106.

Tomás WM, Zucco CA, Fernandez FA, Harris M, Cardim EN, Cestari 
C, da Costa RL, Ferreira VL, Hulle NL, Indrusiak CB, Kalerhoff M, Medeiros TT, Michelson A, Pinheiro RT, Rimoli J, Santos A, Santos Neto JR, Tapia GLG, Tortato MA 2004. Estimativa da abundância das populações de cervo (Blastocerus dichotomus) e veado campeiro (Ozotoceros bazoarticus) no parque estadual do Pantanal do Rio Negro, MS. In Anais do IV Simpósio sobre Recursos Naturais e Sócio-econômicos do Pantanal, Corumbá. Available from: www.cpap.embrapa.br/agencia/simpan/ sumario/artigos/asperctos/pdf/bioticos/618RB-Estimativa $\% 20$ Abund-OKVisto.pdf.

Tomich RGP, Bomfim MRQ, Koury MC, Pellegrin AO, Pellegrin LA, Ko AI, Stancioli EFB 2007. Leptospirosis serosurvey in bovines from Brazilian pantanal using IgG Elisa with recombi- nant protein lipL32 and microscopic agglutination test. Braz $J$ Microbiol 38: 674-680.

Tonin AA, Azevedo MI, Silva AS, Santos LG, Moura Junior J, Martins JLR, Schaefer PC, Badke MRT 2011. Infection in the pampas deer (Ozotoceros bezoarticus) by four serotypes of Leptospira interrogans. Comp Clin Pathol 20: 267-268.

Van Eys GJJM, Gravekamp C, Gerristsen MJ, Quint W, Cornelissen MTE, Ter Schegge J, Terpstra WJ 1989. Detection of leptospiris in urine by polymerase chain reaction. $J$ Clin Microbiol 27: $2258-2262$

Vaughan TA 1986. Mammalogy, 3rd ed., Saunders College Publishing, Philadelphia, 576 pp. 